\title{
What impact did a student exchange have on participating nurses in the longer term?
}

\section{Olav Johannes Hovland}

\section{Førstelektor}

Institutt for helse- og sykepleievitenskap, Fakultet for helse- og idrettsvitenskap,

Universitetet i Agder

\section{Berit Johannessen}

Førsteamanuensis

Institutt for helse- og sykepleievitenskap, Fakultet for helse- og idrettsvitenskap,

Universitetet i Agder

Student exchange

Nurse

Cultural competence

Qualitative method

Tanga International Competence Centre

TICC

Sykepleien Forskning 202116 (86982) (e-86982)

DOI: 10.4220/Sykepleienf.2021.86982en

\section{Summary}

Background: The aim of student exchanges in higher education is to develop personal and professional competence. One of the learning outcomes stipulated for the nursing education is the ability to apply knowledge about cultural competence and understanding. Several studies indicate that student exchanges have a large impact on competence development.

Objective: The objective of this study was to gain insight into how participation in a 12-week student exchange impacted on nurses in the years that followed. 
Method: We conducted qualitative interviews with seven nurses who took part in a student exchange five years earlier.

Results: The nurses described a process in which the exchange helped them develop personal qualities and cultural competence and increased their awareness of how they communicated. In the interviews, the nurses relived situations from their clinical placement in the 'here and now'. Although the nurses found it difficult to define the learning outcomes from the exchange, they indicated that they had learned a great deal. Several of them highlighted how they tried to understand ethnic minority patients and their families and to be understood.

Discussion: The nurses said that the exchange had strengthened their personal and professional development, and continues to do so. Meeting people from a different cultural background to their own in a foreign and unfamiliar culture over a period of time reinforced this effect as the nurses had to find new ways to mobilise their personal and professional resources.

Conclusion: The exchange had a lasting impact on the nurses' personal awareness, professional development and competence development. Meeting people in different situations over a period of time in an unfamiliar culture also helped to strengthen their cultural competence. The nurses found that cultural competence is important for practising nursing in a multicultural society, and that it is difficult to obtain this competence in clinical placements in Norway. However, more research is needed into nurses' experiences from student exchanges, where the focus is on the impact of the exchange on their professional practice.

Student exchanges over a certain time period are one of the most effective ways of developing cultural competence. Students who live in a different culture for a period are 'strangers', and this gives them the opportunity to see how cultures differ (1-4).

Although more research is needed on the learning outcomes of exchanges, studies show that exchanges contribute to personal, professional and cognitive development in the form of strengthened cultural sensitivity and competence (57). Report no. 7 to the Storting (2020-2021) (8) follows up Report no. 16 to the Storting (2016-2017) (9) by emphasising that all students should gain international experience as part of their education, and that student mobility in higher education should be increased. 
International exchanges are also important for educational institutions and society in general because they generate knowledge that cannot be developed by any other means in education programmes (8). Student mobility will strengthen the cultural competence of nursing students. Another one of the goals in nursing education is for pedagogical learning activities to be incorporated into the education, which will help strengthen nurses' knowledge, understanding, commitment and trust in interactions with patients from other cultural backgrounds (10).

One of the learning outcome descriptors in the new national guidelines for nursing education (Section $5 \mathrm{c}$ ) is that the student 'is able to apply knowledge of cultural competence and cultural understanding in nursing assessments, planning, practices and evaluations' (11).

Report no. 16 to the Storting (2016-2017) (9) emphasises that nursing education programmes should qualify candidates to be active, sough-after and responsible participants in the international community. Together with the goal of delivering patient-centred nursing regardless of cultural background, this emphasis actualises nurses' development of cultural competence (12).

Cultural competence can be defined as 'the ongoing process in which the healthcare professional continuously strives to achieve the ability and availability to work effectively within the cultural context of the patient' (12).

Interpersonal encounters are a prerequisite for developing cultural competence, and the competence is developed through five components: 1) awareness of own cultural prejudices, 2) knowledge of cultural and ethnic groups, 3) skills in conducting cultural assessments, 4) encounters with people from a different cultural background, and 5) a desire to develop one's own cultural awareness (13).

Alpers discovered that nurses need better cultural competence in their contact with patients and families from other cultural backgrounds. The competence is linked to communication and interaction, understanding illness and treatment, and how symptoms manifest themselves (14).

A literature review of healthcare personnel's cultural competence shows that it increases significantly following interventions that involve training in cultural competence, and that this increase has a significant association with patient satisfaction (15). 
Since 2008, Norwegian undergraduate nursing students have been able to undertake clinical placements at Tanga International Competence Centre (TICC) in Tanzania (16). The students participate in clinical placements in health clinics, day centres, school health services and retirement homes, and in mental health services in home nursing and outpatient clinics.

Approximately $60-80$ students live at TICC at any one time. The majority are nursing students, but students from other areas of health and social care are also represented. At TICC, the nursing students receive daily supervision in clinical practice from nurses employed by TICC who know the local conditions and culture.

In addition to facilitating learning situations and supervising bedside care, the TICC nurses translate from Swahili into English where necessary. At the end of each day, the students take part in a one-hour reflection group, where they share and reflect on the day's experiences from clinical practice with the supervisor.

Following focus group interviews with 21 students who completed a 12-week clinical placement in their fifth semester at TICC in the autumn of 2015, it was concluded that the students' cultural competence was strengthened during the student exchange (5). Student nurses' experiences of exchanges and the positive impact of student mobility on professional and personal development are well documented, but there is a lack of knowledge on how student exchanges in other cultures impact on nurses in the longer term.

\section{Objective of the study}

The objective of the study was to gain an insight into the impact that the student exchanges at TICC in 2015 had on the participants' nursing practice in the years that followed.

\section{Method}

We conducted individual interviews in order to gain an insight into the impact that student exchanges had had on the nurses in the years that followed (17). The study sample was the 21 nursing students who participated in the focus group interviews in the autumn of 2015 (5).

In connection with the interviews conducted in 2015, the participants gave informed consent to be contacted and participate in a follow-up study. The first author sent out invitations to participate in this follow-up study via text and email in August 2020. Up to two reminders were sent. Eleven nurses declined the invitation, three did not respond, and seven accepted. Six of those who accepted were from the same university, and the seventh was from a different university. 
The first author conducted seven individual interviews during the week commencing 27 September 2020. Due to COVID-19 restrictions and for practical reasons, these interviews were held over the telephone, and were recorded. The interviewer used an interview guide with two main themes: 1) 'Your experiences from the student exchange in 2015', and 2) 'What impact has the exchange had on you in your nursing role?'.

The interviews lasted 37-46 minutes and were transcribed verbatim. The interviewer summarised what had been said throughout the interviews and at the end, and asked the participants to confirm his understanding of the content. NVivo 12 software was used to systematise the data.

Our data analysis was inspired by a three-phase qualitative inductive content analysis: 1) Preparation, 2) Organisation, and 3) Reporting, where the first phase involved a systematic reading of all the interviews in order to gain an overall impression (18).

The 'Organisation' phase consisted of three stages: open coding, categorisation and abstraction. In this phase, we read each interview and coded the meaning of the sentences and paragraphs. Categorising involves collating codes that are considered to belong to the same subcategories from each interview and as a whole. Subcategories that are considered to be linked are grouped together in order to reduce the number of categories. Each author worked independently in the analysis process up to this point.

In the last phase of the process, we discussed and drew up the categories together. The categories formed the basis for an abstraction, which is a general description of the meanings conveyed in the interviews grouped into main categories. In our study, this analysis process resulted in three main thematic categories (18). 
Table 1. Example of the analytical process for a main category. Excerpts from all the interviews.

\begin{tabular}{|c|c|c|c|}
\hline Main category & Grouping & Coding & Meaning \\
\hline \multirow[t]{6}{*}{$\begin{array}{l}\text { Student exchanges } \\
\text { fostered the } \\
\text { development of } \\
\text { personal qualities }\end{array}$} & $\begin{array}{l}\text { Personal } \\
\text { experiences } \\
\text { in inter- } \\
\text { actions with } \\
\text { others }\end{array}$ & $\begin{array}{l}\text { Being a } \\
\text { stranger }\end{array}$ & $\begin{array}{l}\text { 'Having felt it physically, and meeting, and being a } \\
\text { stranger, or from a foreign culture.' } \\
\text { 'It's difficult being a stranger in a different culture, } \\
\text { because your own culture stays with you.' }\end{array}$ \\
\hline & \multirow[t]{2}{*}{$\begin{array}{l}\text { Personal } \\
\text { interest }\end{array}$} & Being present & $\begin{array}{l}\text { 'You have to be a bit where you are when you're there.' } \\
\text { 'I go into every situation with an open mind.' }\end{array}$ \\
\hline & & Interest in others & $\begin{array}{l}\text { 'Taking a little better care of those who you know have gone } \\
\text { through a difficult time.' } \\
\text { 'Showing interest in what they are interested in.' } \\
\text { 'I meet people from different cultures, and I notice that I get, } \\
\text { that my interest is slightly different than it was before.' } \\
\text { 'What's right for me, it's not necessarily right for that pa- } \\
\text { tient.' }\end{array}$ \\
\hline & \multirow[t]{3}{*}{$\begin{array}{l}\text { Personal } \\
\text { development }\end{array}$} & Positive attitude & $\begin{array}{l}\text { 'Many things we should be thankful for here at home.' } \\
\text { 'Seeing something positive in the small things.' }\end{array}$ \\
\hline & & Personal growth & $\begin{array}{l}\text { 'You grow a lot as a person yourself.' } \\
\text { 'I [might] have become more confident.' } \\
\text { 'I [am] more patient.' } \\
\text { 'You grow personally, I try to, like them, always be happy and } \\
\text { positive when I meet people.' } \\
\text { 'In a way, I have a completely different understanding.' } \\
\text { 'I might have a bit more insight into why.' }\end{array}$ \\
\hline & & $\begin{array}{l}\text { Change of } \\
\text { attitude }\end{array}$ & $\begin{array}{l}\text { 'I’m not so judgemental.' } \\
\text { 'Very important to be humble, I've discovered.' } \\
\text { 'You can't judge people.' } \\
\text { 'Well, at least I hope I'm tolerant.' }\end{array}$ \\
\hline
\end{tabular}

The study was approved by the data protection officer at the Norwegian Centre for Research Data (reference number 657253) (19). Information about the study and a consent form were attached to the email invitation to participate. The information letter attached to the email invitation described the procedures regarding data protection, anonymity and the right to withdraw.

This information was orally repeated during the interviews, and oral consent was obtained from all participants before starting the audio recording. The participants were numbered from 1 to 7 to enable us to identify those who might want to withdraw. The audio recordings were stored on a server with two-factor identification and deleted after transcription.

\section{Results}

Table 2 gives an overview of the participants in the study. They completed their bachelor's degree in nursing in the spring of 2016. 
Table 2. Overview of participants

\begin{tabular}{|c|c|c|c|c|c|c|c|}
\hline Nurse & 1 & 2 & 3 & 4 & 5 & 6 & 7 \\
\hline Gender & Male & Female & Female & Female & Female & Female & Female \\
\hline Age & 27 & 27 & 28 & 31 & 28 & 27 & 26 \\
\hline University 1 or 2 & 1 & 1 & 1 & 1 & 1 & 1 & 2 \\
\hline $\begin{array}{l}\text { Workplace } \\
\text { Specialist health service }\end{array}$ & $x(4)$ & $X(1)$ & $x(3)$ & & $x(3)$ & $x(1,5)$ & $x(1,5)$ \\
\hline $\begin{array}{l}\text { Workplace } \\
\text { Primary healthcare service }\end{array}$ & & $x(2)$ & & $x(4)$ & $X(1)$ & $x(1,5)$ & $x(1,5)$ \\
\hline $\begin{array}{l}\text { Workplace } \\
\text { Private sector }\end{array}$ & & & $X(1)$ & & & & \\
\hline $\begin{array}{l}\text { Postgraduate } \\
\text { qualifications }\end{array}$ & $\begin{array}{l}\text { Intensive } \\
\text { care } \\
\text { nursing }\end{array}$ & $\begin{array}{l}\text { Master's } \\
\text { in midwifery }\end{array}$ & --- & --- & --- & $\begin{array}{l}\text { Master's in } \\
\text { midwifery }\end{array}$ & $\begin{array}{l}\text { Public health } \\
\text { nursing }\end{array}$ \\
\hline
\end{tabular}

Where more than one workplace is given in the table, the nurse has changed jobs since they completed their bachelor's degree in nursing in the spring of 2016. Text in bold indicates their current workplace. The figures in brackets indicate the number of years of employment.

The interviews with the nurses showed that their experiences from the student exchange in 2015 and the impact it had in the years that followed can be divided into three main categories:

- Student exchange fostered the development of personal qualities

- Student exchange increases awareness about communication

- Student exchange fostered the development of cultural competence

All the nurses indicated that they had learned a lot during their stay at TICC, but when they were asked to give examples of what they had learned, they found it difficult to be specific or to provide examples.

\section{«They relived situations from maternity wards, school health services, clinics or home visits in the 'here and now'.»}

In the interviews, however, several nurses said that discussing the exchange was making them reminisce about Tanzania. They relived situations from maternity wards, school health services, clinics or home visits in the 'here and now', and described how these experiences have subsequently had a major impact on them. Several nurses also pointed out that the daily reflection groups at TICC had a major impact on their learning process. 


\section{Student exchange fostered the development of personal qualities}

Overall, the nurses gave the clear impression that the student exchange had strengthened their personal qualities. Nurse number 2 described her experience as follows:

'You're young, and you're a nursing student, and you think you're going to save the world and, yeah, help other people. Then you go down there and suddenly realise that "Oh! Things are maybe not quite as I thought they were", and you grow a lot as a person. Then you start to see the bigger picture and start thinking. You start to reflect a lot on why things are the way they are. And you grow both as a human being, within yourself, and in your role as a professional. I was a different person when I came back.'

\section{«Others emphasised that they had become more tolerant and less judgemental.»}

Other nurses said that the student exchange had taught them to be more patient. One said she was patient before the exchange, but that this quality was strengthened due to the awareness she gained from the new experiences in Tanzania. Others emphasised that they had become more tolerant and less judgemental. They now exhibit a deeper understanding of differences during their interactions with other people, regardless of cultural background.

The nurses described how their ability to understand other people's situations had improved, and how they were 'more affable and generous' when talking to patients. They had generally become more interested in people and more aware that people can have their own reasons for their choices and actions. One nurse indicated that she now pays more attention to what others think, believe and feel.

Several nurses linked their personal development to their professional development in their role as a nurse. One nurse said that she had taught refugees, a task she would have turned down without the professional confidence she developed during her student exchange. However, the nurses did not regard the exchange as an isolated factor in their personal and professional development, but as a significant contributor to their already ongoing development.

\section{Student exchange increased awareness about communication}

The nurses gained a variety of experiences within communication during the student exchange, and they emphasised the importance of understanding and being understood. During the exchange, they learned to adapt their communication with patients and families to cultural frameworks and conditions. One nurse said that she tries to be very precise when explaining to minority patients why things are done a certain way, as she is aware that they might have done it differently. 
Several nurses indicated that the student exchange had made them more aware of how they communicate with patients and families. Nurse 1 said the following:

'I've become very aware of how I communicate. Because I think that if it was me who had been there [in Tanga], I would've wanted as much information as possible. And I also think that if I get someone from a foreign culture, then I think they maybe communicate in a completely different way, and their need for information.'

\section{«The nurses were foreigners in an unfamiliar culture.»}

Nurse 2 pointed out that she has become more aware of how she communicates: she facilitates dialogue and builds trust by showing interest in the patient in her communication, and emphasises that she is there for their benefit. The patients respond well when she shows that she is trying to understand.

The nurses were foreigners in an unfamiliar culture, and they now draw on this experience when they meet people who do not speak good Norwegian and who are foreigners in Norway:

'I think maybe the fact that I've felt 'nobody understands what I mean, and nobody understands what I want or what I want to accomplish', it's frustrating. So I think, maybe that's one of the things I've learned from TICC. That sense of how different cultures actually are. And you're not able to do anything. You couldn't say anything. And that was also maybe a big lesson that we learned (Nurse 6).'

The nurses described how being a stranger in a culture with a foreign language has made them more understanding, and taught them to be more patient and to consider other perspectives when communicating with people from a different cultural background. This approach also applies to communication with ethnic Norwegian patients whose understanding of their situation differs to that of the nurse.

\section{Student exchange fostered the development of cultural competence}

The last main category covers the nurses' experiences of increased cultural understanding following their stay at TICC. Nurse 1 explained the following: 
'I've applied it to my work in Norway. Because I often find in hospitals that a lot [of colleagues] don't understand why people from other cultures like to bring so many relatives with them. So it's about them having that expectation from their own country in a way. The expectation that they can bring a lot of their family so they can take on some of the work. However, I think that those of us who have that cultural understanding should of course share it with our colleagues. But you're at least aware that you're not familiar with the culture. And I think that's something you're not aware of if you haven't been on a cultural exchange like this.'

The nurses said that being in a different culture over a period of time has given them a new understanding of the importance of a person's culture. They extend this to include people from different environments to themselves, and Nurse 7 describes it as follows:

'It's the same kind of thing, you do things in a slightly different way because you grew up in a different environment. I think it's interesting to see how people think differently. Or how different things can be for me compared to them. Or how different the world looks [to them].'

\section{Discussion}

The objective of the study was to gain an insight into the experiences of nurses who took part in a 12-week student exchange five years earlier. The nurses emphasised that the variety of encounters they had with people in clinical practice and in daily life in Tanga have had a major impact on their personal and professional development.

Interpersonal encounters are a prerequisite for developing cultural competence (13) because this interaction generates knowledge about other people and cultures, helps to develop skills in assessing the context and deepens the understanding of how culture manifests itself in people's daily lives.

Being strangers in an unfamiliar culture helped to strengthen the nurses' development process. The nurses' experiences in Tanga differed to those from earlier clinical placements in Norway due to the diversity of new situations from daily life and clinical practice, combined with a lack of proficiency in the language of the host country.

\section{Student exchange reinforced personal development}

Several nurses emphasised that the student exchange reinforced their already ongoing personal development. The personal development also impacted on their professional development, which may partly be explained by the need to find new ways to mobilise personal and professional resources in their interactions with the people they met in clinical practice. 
This is an important point in the discussion about the content and benefits of student exchanges, as competence entails 'the ability to mobilise knowledge, skills, attitudes and values, combined with a reflective learning process, in order to engage and interact' (20).

\section{The nurses applied their experiences from the exchange to their daily work}

The nurses were unable to describe and define their own learning outcomes. This may be because their stay at TICC was five years ago, and over time, many experiences are transformed into general impressions. In the study from 2015, where the nurses participated as students, many of them said that 'they discovered new sides of themselves, but that they would not see the implications of this until some time had passed' (5).

A common thread in the interviews was that during the 12-week exchange, the nurses had a good opportunity to experience and reflect on the differences between people and cultures. The experiences and reflections over time led to an increased awareness of cultural differences and their own personal development $(4,5)$.

\section{«The nurses had a good opportunity to experience and reflect on the differences between people and cultures.»}

Meeting patients with a different cultural background was good training (15), and it strengthened their cultural competence by deepening their professional understanding of illness and treatment and of how symptoms manifested themselves in the patients (14). Nursing education in Norway does not offer the same scope of practical experiences and learning outcomes as TICC, and the nurses emphasised that they use their experiences from the exchange in their daily work as nurses.

Living at close quarters with 60-80 other Norwegian students was a challenge, but they discussed and processed their experiences from clinical practice and daily life, which in itself was beneficial to learning. In addition to the objective learning outcomes found in policy documents, regulations and programme descriptions, the students' shared living situation was also conducive to developing cultural competence. The nurses said that discussing and processing experiences at TICC was an approach they have subsequently adopted with colleagues in the Norwegian health service (21-23). 
The personal and professional development that the student exchange fostered in nurses is an important argument for developing initiatives and providing more opportunities for students and staff to acquire international experience in the Norwegian nursing education (8-10). New initiatives should also involve patients, their families and staff from different cultural backgrounds, because this gives students the opportunity to apply and develop their cultural competence throughout their education (11).

\section{Strengths and weaknesses of the study}

One of the strengths of the study is that the participants were taken from the sample in the 2015 study. It can be both a strength and a weakness that both authors had the same prior understanding after several years of collaboration on internationalisation in nursing (24). However, neither of the authors had had contact with the nurses since 2015 . The credibility of the study was enhanced since both authors analysed the interview material and identified the same themes (25).

One of the weaknesses of the study is that only seven of the 21 students from 2015 participated, and we do not know how the other 14 would have responded. Another weakness is that memories may have faded after five years. Virtually all the nurses indicated that they had learned a lot during their stay at TICC and had developed considerably, but when asked about the learning outcomes, they found it difficult to be specific or to provide examples. Nevertheless, the nurses said that the experiences from the exchange were important for their professional practice.

\section{Conclusion}

The study examined the impact that a 12-week student exchange five years earlier had had on seven nurses in the years that followed. The results showed that the exchange had had long-lasting effects on their personal awareness and professional development, and increased their competence. Interpersonal encounters in different situations in an unfamiliar culture over a period of time also strengthened their cultural competence, which is particularly important for the nurses in their daily professional practice in a multicultural society.

The participants linked the experiences from the exchange to personal qualities and skills they had prior to the exchange. The exchange therefore served to raise their awareness in the process of developing personal and professional competence as a nurse. We recommend further research into nurses' experiences from student exchanges, where the emphasis is on identifying the impact on professional practice. 
- Student exchanges are the subject of much discussion in the academic community, and there is an abundance of literature on nursing students' experiences from student exchanges, where learning outcomes and personal and professional development are well documented.

- In this study, we followed up seven nurses who undertook a 12-week clinical placement in Tanzania in the autumn of 2015 as part of a student exchange. The exchange was part of their bachelor's degree in nursing. We conducted seven individual qualitative interviews with two main themes: 1) 'Your experiences from the student exchange in 2015', and 2) 'What impact has the exchange had on you in your nursing role?'.

- The study documented the impact that a 12-week student exchange had on seven nurses over the five-year period following the exchange. This generated relevant knowledge on how they developed cultural competence, and the effect that the exchange has had on their nursing practice.

\section{References}

1. Edmonds ML. An integrative literature review of study abroad programs for nursing students. Nurs Educ Perspect. 2012;33(1):30-4. DOI: 10.5480/1536-5026$\underline{33.1 .30}$

2. Kelleher S. Perceived benefits of study abroad programs for nursing students: an integrative review. J Nurs Educ. 2013;52(12):690-5. DOI: 10.3928/01484834-20131118-01

3. Maltby HJ, de Vries-Erich JM, Lund K. Being the stranger: comparing study abroad experiences of nursing students in low and high income countries through hermeneutical phenomenology. Nurse Educ Today. 2016;45:114-9. DOI:

$\underline{10.1016 / j . n e d t .2016 .06 .025}$

4. Jansen MB, Lund DW, Baume K, Lillyman S, Rooney K, Nielsen DS. International clinical placement - experiences of nursing students' cultural, personal and professional development; a qualitative study. Nurse Educ Pract. 2021;51:102987. DOI: 10.1016/j.nepr.2021.102987

5. Hovland OJ, Johannessen B. Sykepleierstudenter utvikler kulturell kompetanse på utveksling i Tanzania. Sykepleien Forskning. 2018;13(73782):(e73782). DOI: $\underline{\text { 10.4220/Sykepleienf.2018.73782 }}$

6. Kohlbry PW. The impact of international service-learning on nursing students' cultural competency. J Nurs Scholarsh. 2016;48(3):303-11. DOI:

$\underline{10.1111 / \mathrm{jnu} .12209}$ 
7. Westerbotn M, Kneck $\AA$, Hovland OJ, Elrond M, Pedersen I, Lejonqvist G-B, et al. Taking part in Nordic collaboration; nursing students' experiences and perceptions from a learning perspective: a qualitative study. Nurse Educ Today. 2015;35(5):712-7. DOI: 10.1016/j.nedt.2015.01.025

8. Meld. St. 7 (2020-2021). En verden av muligheter. Internasjonal studentmobilitet i høyere utdanning. Oslo: Kunnskapsdepartementet; 2020. Available at: https://www.regjeringen.no/no/dokumenter/meld.-st.-720202021/id2779627/ (downloaded 06.01.2021).

9. Meld. St. 16 (2016-2017). Kultur for kvalitet i høyere utdanning. Oslo: Kunnskapsdepartementet; 2017. Available at:

https:/www.regjeringen.no/no/dokumenter/meld.-st.-16-20162017/id2536007/ (downloaded 06.01.2021).

10. O'Brien E-M, O’Donnell C, Murphy J, O’Brien B, Markey K. Intercultural readiness of nursing students: an integrative review of evidence examining cultural competence educational interventions. Nurse Educ Pract. 2021;50:102966. DOI: $\underline{10.1016 / j . n e p r .2021 .102966}$

11. Kunnskapsdepartementet. Forskrift 15. mars 2019 nr. 412 om nasjonal retningslinje for sykepleierutdanning. Available at: https://lovdata.no/dokument/SF/forskrift/2019-03-15-412 (downloaded 29.09.2020).

12. Campinha-Bacote J. Delivering patient-centered care in the midst of a cultural conflict: the role of cultural competence. Online J Issues Nurs. 2011;16(2):5.

13. Campinha-Bacote J. Coming to know cultural competence: an evolutionary process. International Journal for Human Caring. 2011;15(3):42-8. DOI: $\underline{10.20467 / 1091-5710.15 \cdot 3 \cdot 42}$

14. Alpers LM. Helsepersonells kompetansebehov i møte med etniske minoritetspasienter. Oslo: Høgskolen i Oslo og Akershus; 2017. Available at: https://hdl.handle.net/10642/5019 (downloaded 05.05.2021).

15. Govere L, Govere EM. How effective is cultural competence training of healthcare providers on improving patient satisfaction of minority groups? A systematic review of literature. Worldviews Evid Based Nurs. 2016;13(6):402-10. DOI: $10.1111 /$ wvn.12176

16. TICC. Tanga Intl. Competence Center. Tanga: TICC; 2019. Available at: https://ticc.org/ (downloaded 06.01.2021). 
17. Kvale S, Brinkmann S. Det kvalitative forskningsintervju. 3 rd ed. Oslo: Gyldendal Akademisk; 2015.

18. Elo S, Kyngäs H. The qualitative content analysis process. J Adv Nurs. 2008;62(1):107-15. DOI: 10.1111/j.1365-2648.2007.04569.x

19. Norsk senter for forskningsdata (NSD). Om NSD - Norsk senter for forskningsdata. Bergen: NSD. Available at: http://www.nsd.uib.no/ (downloaded 19.05.2021).

20. NOU 2018: 2. Fremtidige kompetansebehov 1. Kunnskapsgrunnlaget. Departementenes servicesenter, Informasjonsforvaltning; 2018. Available at: https://www.regjeringen.no/no/dokumenter/nou-2018-2/id2588070/ (downloaded 07.01.2021).

21. Rommetveit R. Læring gjennom dialog: ei sosiokulturell og sosiokognitiv tilnærming til kunnskap og læring. In: Dysthe O, ed. Ulike perspektiv på læring og læringsforskning. Oslo: Cappelen Damm Akademisk; 1996. pp. 88-104.

22. Säljö R. Lärande i praktiken: ett sociokulturellt perspektiv. Stockholm: Prisma; 2000.

23. Wenger E. Communities of practice: learning, meaning, and identity. Cambridge: Cambridge University Press; 1998.

24. Graneheim UH, Lindgren B-M, Lundman B. Methodological challenges in qualitative content analysis: a discussion paper. Nurse Educ Today. 2017;56:29-34. DOI: $\underline{10.1016 / j . n e d t .2017 .06 .002}$

25. Graneheim UH, Lundman B. Qualitative content analysis in nursing research: concepts, procedures and measures to achieve trustworthiness. Nurse Educ Today. 2004;24(2):105-12. DOI: 10.1016/j.nedt.2003.10.001 